\title{
Health Repercussions of a Culture of Fear Within Undocumented Immigrant Communities
}

\author{
Matthew Stutz, MD' ${ }^{7}$, Vanessa Rivas-Lopez, $M D^{2}$, Brian Lonquich, $M D^{3}$, and \\ Arshiya A. Baig, MD
}

'Department of Medicine, Section of Pulmonary and Critical Care, University of Chicago, Chicago, IL, USA; ${ }^{2}$ Erie Family Health Centers, Northwestern University Feinberg School of Medicine, Chicago, IL, USA; ${ }^{3}$ Department of Pediatrics, Section of Emergency Medicine, Baylor College of Medicine, Houston, TX, USA; ${ }^{4}$ Department of Medicine, Section of General Internal Medicine, University of Chicago, Chicago, IL, USA.

KEY WORDS: immigration; healthcare policy; social determinants of health.

J Gen Intern Med 34(9):1903-5

DOI: $10.1007 / \mathrm{s} 11606-019-05161-\mathrm{w}$

(c) Society of General Internal Medicine 2019

I mmigration status is an increasingly relevant social determinant of health that has detrimental implications for the health, safety, and well-being of the roughly 11 million undocumented immigrants living in the USA. ${ }^{1-3}$ The ability and willingness of this marginalized population to seek healthcare is often affected by cost, language, and knowledge of the healthcare system. Additionally limiting is fear of discrimination and deportation exacerbated by anti-immigrant rhetoric and policies that permeate immigrant communities with a culture of fear. ${ }^{4,5}$ This culture of fear has a negative impact on patient's mental and physical health, and contributes to patients delaying or avoiding care. ${ }^{6,7}$

Over the last decade, the US Government's focus on border security, processing of undocumented immigrants, and deportation has contributed to a culture of fear within undocumented communities. During the Obama administration, deportation of undocumented immigrants increased substantially. ${ }^{8}$ The Trump administration has additionally targeted undocumented immigrants through memorandums, appointments, and changes in policy. On September 5, 2017, the Trump administration announced it would end the Deferred Action for Childhood Arrivals (DACA) program, excluding 800,000 youth and young adults from the opportunity to legally work and obtain higher education in the USA. ${ }^{9}$ It is still unclear how DACA will be reformed or dismantled, but what is clear is that efforts such as these will have lasting implications within undocumented communities. In addition, on October 17, 2017, Thomas Homan, the former director of Immigrations and Customs Enforcement (ICE), announced he planned to

Received August 9, 2018

Revised November 28, 2018

Accepted June 18, 2019

Published online July 16, 2019 "quintuple" worksite enforcement actions. ${ }^{10}$ This statement foreshadowed coordinated sweeps of 98 Seven-Eleven stores across 17 states to deport undocumented employees on January 10, 2018. Perhaps the most frightening example of the interplay between ICE and undocumented communities is the case of Rosamaria Hernandez, a 10-year-old child with cerebral palsy who was detained as she was being transported via ambulance between hospitals for emergency surgery. ${ }^{11}$

Poor access to medical care is one of many forms of health discrimination that undocumented immigrants face, which leads to poor healthcare outcomes and lower quality of life. ${ }^{12}$ For instance, excluding undocumented immigrants from healthcare has been found to lead to small increases in the incidence of infectious diseases. ${ }^{13}$ Fear of immigration enforcement has also been identified as a reason patients with tuberculosis delay seeking care, which threatens both individual and public health. ${ }^{14}$ Furthermore, undocumented immigrants with end-stage kidney disease who were dependent on emergent dialysis due to their immigration status were found to have high rates of unexpected death due to cardiac arrhythmias. ${ }^{15}$ Findings such as these have led the American Public Health Association to recognize exclusionary immigration policies as harmful to undocumented immigrants' health. ${ }^{16,17}$

There has long been concern regarding the treatment of undocumented immigrants during the deportation process. Recent media coverage of the separation of immigrant families has increased public awareness about the severity of the issue. Separating children from their parents clearly places them under toxic stress which has been proven to have a detrimental impact on brain development and increase the risk of posttraumatic stress disorder. ${ }^{12}$ A 2018 study found that immigrant children separated from their parents had significantly higher risk of emotional and behavioral problems as well as lower literacy rates. ${ }^{18}$ Children and adolescents who are exposed to toxic stress suffer from life-long mental health illness, impaired ability to learn, poor adaptive behaviors, and decreased adult productivity. ${ }^{19}$ We thus surmise that children raised in a culture of fear due to immigration status are likely to experience toxic stress with enduring effects on their mental, emotional, and physical wellbeing.

Exclusionary tactics and policies aim to reduce undocumented immigrants access to healthcare and social services. 
These practices have been shown to be deleterious to the health of undocumented immigrants and result in increased health costs. ${ }^{20,21}$ Provision of healthcare to immigrants is often met with concern for over-utilization of healthcare resources and excessive cost. However, undocumented immigrants tend to use the healthcare system less and have lower associated health costs than native citizens in the USA. ${ }^{22,23}$ In contrast, inclusive policies such as DACA that worked to incorporate long-standing undocumented residents into society led to improved self-perception of health, utilization of social services, and access to physicians/mental health professionals. ${ }^{24,}{ }^{25}$ Furthermore, Sweden's health policy which provides a range of care to undocumented immigrants has cost much less than predicted. ${ }^{26}$

The USA frequently offers undocumented immigrants economic advantage, sanctuary from violence, and improved quality of healthcare than offered in native countries. Unfortunately, once undocumented immigrants are in court, they are often deported even if they are lawfully in the USA. The importance of representation is immense as immigrants with attorneys present for their proceedings were four times more likely to be released from detention and twice as likely to obtain the immigration relief they sought. ${ }^{27}$ By partnering with and distributing information for reputable legal advocacy organizations, healthcare providers can help prevent patients from being deported and falling victim to immigration law fraud. Identifying a licensed attorney who specializes in and practices immigration law is ideal as immigration law is extremely complex and frequently changes. While a specialized attorney is preferred, there are unfortunately few attorneys who specialize in immigration law and cost is often prohibitive. Physicians should also know immigration law fraud is unfortunately common and can have devastating consequences involving financial strain, delayed application for citizenship, declined applications, and/or deportation. ${ }^{28}$ To assist patients who may encounter immigration authorities, physicians can provide cards generated by the National Immigration Law Center entitled "Know Your Rights" that outline protected civil liberties; immigrants can hand these cards to immigration officials if they are detained.

Healthcare providers are under no legal obligation to inquire into or report immigration status to authorities. This argument stems from the first amendment which protects the right to free speech but also the right to not speak. Physicians are mandated reporters in some circumstances such as child or elder-abuse; however, reporting undocumented immigrants is not an obligation and could violate the Health Insurance Portability and Accountability Act (1996). ${ }^{29}$ Furthermore, healthcare professionals are encouraged not to inquire about patients' immigration status and are discouraged from including that information in patients' medical record or billing information. ${ }^{30}$ Lastly, Immigrations and Customs Enforcement (ICE) as well as Customs and Border Patrol (CBP) have both issued memoranda that consider clinics and hospitals to be "sensitive locations," where immigration enforcement is to be avoided unless officers have obtained official approval. ${ }^{31}$

In summary, undocumented immigrants suffer poor health outcomes, particularly regarding mental health, with life-long consequences. It is imperative that physicians recognize the barriers to care undocumented immigrants face and help by protecting their immigration status, identifying immigration attorneys in the area, and distributing "Know Your Rights" materials. Lastly, providing compassionate care with an informed understanding of the social, legal, and economic barriers undocumented immigrants encounter will combat the culture of fear and improve the health of this vulnerable population.

Corresponding Author: Matthew Stutz, MD; Department of Medicine, Section of Pulmonary and Critical Care University of Chicago, Chicago, IL, USA (e-mail: matthew.stutz@uchospitals.edu).

\section{Compliance with Ethical Standards:}

Conflict of Interest: The authors have no conflicts of interest to disclose.

\section{REFERENCES}

1. Castaneda H, Holmes SM, Madrigal D, Trinidad Young M, Beyeler N, Quesada J. Immigration as a Social Determinant of Health. Annu Rev Public Health 2015: (36) 375-92.

2. Hacker K, Chu J, Arsenault L, Marlin RP. Providers Perspectives on the Impact of Immigration and Customs Enforcement (ICE) Activity on Immigrant Health. J Health Care Poor Underserved 2012: 23(2): 651-65.

3. http://www.pewresearch.org/fact-tank/2015/01/15/immigration. Accessed 1/29/19.

4. Hacker K, Anies MR, Folb BL, Zallman L. Barriers to Healthcare for Undocumented Immigrants: A Literature Review. Risk Manag Helathc Policy 2015: (8) 175-183.

5. Larchanche S. Intangible Obstacles: Health Implications of Stigmatization, Structural Violence, and Fear Among Undocumented Immigrants in France. Soc Sci Med 2012: 74(6) 858-863.

6. Asch S, Beake B, Gelberg L. Does Fear of Immigration Authorities Deter Tuberculosis Patients From Seeking Care? West J Med 1994: 161(4): 373-376.

7. Larchanche S. Intangible Obstacles: Health Implications of Stigmatization, Structural Violence, and Fear Among Undocumented Immigrants in France. Soc Sci Med 2012: (74) 585-863.

8. https://www.dhs.gov/immigration-statistics/yearbook. Accessed 1/29/ 19.

9. Uwemedimo OT, Monterrey AC, Linton JM. A Dream Deferred: Ending DACAThreatens Children, Families, and Communities. Pediatrics. 2017: (6) $1-3$.

10. https://www.cnn.com/2017/10/17/politics/ice-crackdown-workplaces/index.html. Accessed 1/29/19.

11. https://www.npr.org/sections/thetwo-way/2017/11/03/562003841/ girl-detained-by-border-patrol-after-emergency-surgery-is-released-toparents. Accessed 1/29/19.

12. Gostin LO, Ó Cathaoir KE. Presidential Immigration Policies Endangering Health and Well-being? JAMA. 2017; 317(16) 1617-1618.

13. Peralta-Gallego L, Gene-Badia J, Gallo P. Effects of Undocumented Immigrants Exclusion from Health Care Coverage in Spain. Health Policy 2018; (122) 1155-1160.

14. Asch S, Leake B, Anderson R, Gelberg L. Why do symptomatic patients delay obtaining care for tuberculosis? Am J Respir Crit Care Med 1998: 157(4):1244-1248.

15. Cervantes L, O'Hare A, Choncol M, Hull M, Van Bockern J, Thompson M, Zoucha J. Circumstances of Death Among Undocumented Immigrants 
Who Rely on Emergency Only Hemodialysis. CJASN. 2018: (9) 14051406.

16. APHA (Am. Public Health Assoc.). 2009 Border Crossing Deaths: A Public Health Crisis Along the US-Mexico Border. Washington, DC: APHA.

17. APHA (Am. Public Health Assoc.). 2012. Opposing the DHS-ICE Secure Communities Program. Washington, DC: APHA

18. Lu T, He Q, Brooks-Gunn J. Diverse Experience of Immigrant Children: Do Separation and Reunification Shape Development? Child Dev. 2018. Online ahead of print.

19. Garner AS, Shonkoff JP, Committee on Psychosocial Aspects of Child and Family Health, Committee on Early Childhood, Adoption, and Dependent care, Section on Developmental and Behavioral Pediatrics. Pediatrics. 2012: 129 (1) 224-231.

20. Allen B, Cisneros EM, Tellez A. The children left behind: the impact of parental deportation on mental health. J Child Fam Stud 2015: 24 (2) 386-392.

21. Stutz and Baig. International examples of undocumented immigration and the affordable care act. J Immigr Minor Health 2014: 16(4) 765-8.

22. Pourat N, Wallace SP, Hadler MW, Ponce D. Assessing Health Care Services Used By California's Undocumented Immigrant Population in 2010. Health Aff 2014: 33 (5) 840-847

23. Stimpson JP, Wilson FA, and Eschbach K. Trends in health care spending for immigrants in the United State. Health Aff (Millwood) 2010: (3) 544550.

24. Sudhinaraset M, To TM, Ling I, Melo J, Chavarin J. The Influence of Deferred Action for Childhood Arrivals on Undocumented Asian and Pacific Islander Young Adults: Through a Social Determinants of Health Lens. J Adolesc Health 2017: (60) 741-746.

25. Venkataramani M, Pollack CE, DeCamp LR, Leifheit KM, Berger ZD, Venkataramani AS. Association of Maternal Eligibility for the Deferred Action for Childhood Arrivals Program With Citizen Children Participation in the Women, Infants, and Children Program JAMA Pediatr. 2018. (172) 699-701.

26. Swedish Agency for Public Management Report. Vård till papperslösa [Swedish]. 2015. http://www.statskontoret.se/globalassets/ publikationer/2015/201510.pdf. Accessed 1/29/19.

27. https://www.americanimmigrationcouncil.org/research/access-counsel-immigration-court. Accessed 1/29/19.

28. Langford A. What's in a Name? Notarios in the United States and the Exploitation of a Vulnerable Latino Immigrant Population. Harvard Latino L Rev 2004: (115) 119-120.

29. Sconyers J and Tate T. How Should Clinicians Treat Patients who Might be Undocumented. AMA J Ethics 2016: 18(3) 229-236.

30. The National Immigrant Law Center. https://www.nilc.org/issues/immigration-enforcement/healthcare-provider-and-patients-rights-imm-enf/ The National Immigrant Law Center. Accessed 1/29/19.

31. See Memorandum from John Morton, Director, U.S. Immigration and Customs Enforcement, to Field Office Directors, et al., subject: Enforcement Actions at or Focused on Sensitive Locations, Oct. 24, 2011, https://www.ice.gov/doclib/ero-outreach/pdf/10029.2-policy.pdf; and Memorandum from David V. Aguilar, Deputy Commissioner, U.S. Customs and Border Protection, subject: U.S. Customs and Border Protection Enforcement Actions at or Near Certain Community Locations, Jan. 18, 2013, https://foiarr.cbp.gov/docs/Policies_and_Procedures/ 2013/826326181_1251/1302211111_CBP_Enforcement_Actions_at_or Near_Certain_Community_Locations_\%7BSigned_M.pdf. Accessed 1/29/19.

Publisher's Note Springer Nature remains neutral with regard to jurisdictional claims in published maps and institutional affiliations. 